\title{
Pengeluaran Pemerintah dan Pertumbuhan Ekonomi di Indonesia : Analisis Panel Seemingly Unrelated Regression
}

\author{
Bayu Kharisma ${ }^{1}$ Adji Pratikto ${ }^{2}$ \\ ${ }^{1}$ Departemen Ilmu Ekonomi, Fakultas Ekonomi dan Bisnis, Universitas Padjadjaran \\ ${ }^{2}$ Departemen Ilmu Ekonomi Universitas Katolik Indonesia Atma Jaya, Jakarta
}

\begin{abstract}
The paper aims to examine how the growth impact of government spending in Indonesia, with a focus on several expenditure sectors, namely defense, education, health, agriculture, transport and communications, and manufacturing sectors. Based on the 17 sectors studied, only 6 sectors significantly influence economic growth, namely industrial sector, agriculture and irrigation sector, transportation and transportation sector, environment and spatial sector, political sector and mass media lighting, and security of order. Meanwhile, of the six sectors, only the security sector of order has a positive effect on economic growth, while the other five sectors negatively affect economic growth. If not paid attention to the level of significance, almost all sectors of development expenditure have a negative impact on economic growth, only 5 sectors that have a positive influence that is the labor sector, education sector, national culture, trust in God YME, youth and sports, housing and residential sector, the science and technology sector, as well as the security and order sectors. However, only the security sector of order has a significant effect, while the other four sectors have no significant effect. This result differs from previously conclusions, where their overall conclusion of the government development spending sector has a significant effect, the effect being positive. However, the same conclusions are generated for the security and order sectors, where the results are positive and significant.
\end{abstract}

\begin{abstract}
Abstrak
Paper ini bertujuan untuk melihat bagaimana dampak pertumbuhan dari pengeluaran pemerintah di Indonesia, dengan fokus pada beberapa sektor pengeluaran, yaitu sektor pertahanan, pendidikan, kesehatan, pertanian, transportasi dan komunikasi, dan manufacturing. Berdasarkan 17 sektor yang diteliti, hanya 6 sektor yang berpengaruh secara signifikan terhadap pertumbuhan ekonomi, yaitu sektor industri, sektor pertanian dan pengairan, sektor transportasi dan perhubungan, sektor lingkungan hidup dan tata ruang, sektor politik dan penerangan media massa, dan keamanan ketertiban. Sementara itu, dari ke enam sektor tersebut, hanya sektor keamanan ketertiban yang berpengaruh secara positif terhadap pertumbuhan ekonomi, sedangkan ke 5 sektor lainnya berpengaruh secara negatif terhadap pertumbuhan ekonomi. Apabila tidak diperhatikan taraf signifikansinya, hampir keseluruhan sektor pengeluaran pembangunan memiliki pengaruh yang negatif terhadap pertumbuhan ekonomi, hanya 5 sektor yang memiliki pengaruh positif yaitu sektor tenaga kerja, sektor pendidikan, kebudayaan nasional, kepercayaan terhadap Tuhan YME, pemuda dan olahraga, sektor perumahan dan pemukiman, sektor ilmu pengetahuan dan teknologi, serta sektor keamanan dan ketertiban. Akan tetapi hanya sektor keamanan ketertiban yang berpengaruh secara signifikan, sedangkan ke empat sektor lainnya tidak berpengaruh secara signifikan. Hasil ini berbeda dengan kesimpulan Niloy Bose et al (2007), di mana keseluruhan sektor pengeluaran pembangunan pemerintah yang berpengaruh signifikan, pengaruhnya adalah positif. Akan tetapi kesimpulan yang sama dihasilkan untuk sektor keamanan dan ketertiban, di mana hasilnya adalah positif dan signifikan.
\end{abstract}

1 * Corresponding author, email address: ${ }^{1}$ bayu.kharisma@unpad.ac.id 


\section{Latar Belakang Masalah}

Salah satu fungsi pemerintah di dalam perekonomian ialah menyediakan barang publik. Secara teoritis, barang publik merupakan barang yang dibutuhkan oleh masyarakat untuk melaksanakan aktivitas ekonominya, akan tetapi mekanisme pasar tidak mampu untuk menyediakan barang tersebut. Ketidakmampuan mekanisme pasar untuk menyediakan barang publik tersebut karena adanya dua karakteristik yang melekat pada barang publik yaitu non excludable dan non-rivalry (Mankiw 2009).

Barang publik dikatakan memiliki karakteristik non excludable, karena apabila barang publik telah tersedia bagi masyarakat, maka seluruh anggota masyarakat dapat menggunakan barang tersebut, tanpa pemerintah mampu untuk menghalangi orang yang tidak membayar pajak untuk turut serta menikmatinya. Selain memiliki karakteristik non-exclusionary, barang publik juga dikatakan memiliki karakteristik non-rivalry. Hal ini dikarenakan apabila seorang anggota masyarakat telah mengkonsumsi barang publik tersebut, maka tidak akan mengurangi kesempatan orang lain untuk menggunakan barang yang sama.

Salah satu contoh dalam barang publik adalah jalan raya, yang sangat dibutuhkan oleh masyarakat untuk melaksanakan aktivitas ekonominya. Apabila pemerintah telah menyediakan jalan raya, maka siapapun dapat menggunakan jalan raya tersebut dengan bebas, dan pemakaian jalan raya dari seorang anggota masyarakat, sampai dengan batas tertentu, tidak akan mengurangi jalan raya yang tersedia bagi anggota masyarakat lainnya. Dengan demikian, akan muncul insentif bagi seluruh anggota masyarakat untuk menikmati barang publik tersebut tanpa membayar, sehingga mekanisme pasar tidak akan mampu untuk menyediakan barang tersebut secara efisien. Oleh karena itu, dapat dilihat bahwa peranan pemerintah dalam mendukung aktivitas perekonomian sehingga dapat mencapai pembangunan yang berkelanjutan sangat dibutuhkan. Akan tetapi di sisi lain, untuk menyediakan barang publik tersebut, pemerintah mengandalkan penerimaan dari sektor pajak.

Kebijakan pajak tersebut kemungkinan dapat mendistorsi pasar karena dapat menghasilkan crowding out effect, sehingga pasar tidak dapat bekerja secara optimal untuk menghasilkan output dengan cara yang paling efisien. Dengan demikian, dapat disimpulkan bahwa peranan pemerintah dalam perekonomian memiliki dua sisi mata uang yang berbeda, di satu sisi dapat mendorong perekonomian untuk bekerja lebih baik, akan tetapi di sisi lain juga memiliki sisi untuk mendistorsi pasar sehingga pasar tidak dapat bekerja secara optimal. Oleh karena itu perlu diteliti mengenai peranan pemerintah di dalam mendorong pertumbuhan ekonomi, agar dapat dilihat seberapa jauh efektivitas dari kegiatan pemerintah dalam perekonomian.

Model dalam penelitian ini dibangun dari paper yang berjudul 'Public Expenditure and Economic Growth: A Disaggregated Analysis for Developing Countries' yang ditulis oleh Niloy Bose, M. Emranul Haque dan Denise R. Osborn. Di dalam paper tersebut dilihat bagaimana dampak pertumbuhan dari pengeluaran pemerintah untuk tiga puluh negara sedang berkembang dari tahun $1970 \mathrm{~s} / \mathrm{d}$ 1990, dengan fokus pada beberapa sektor pengeluaran, yaitu sektor pertahanan, 
pendidikan, kesehatan, pertanian, transportasi dan komunikasi, dan manufacturing. Ada dua temuan penting di dalam paper mereka yaitu (Bose, Haque et al. 2007)

1. Bagian dari pengeluaran investasi pemerintah dalam Produk Domestik Bruto berkorelasi secara positif dan signifikan terhadap pertumbuhan ekonomi, sedangkan dampak pertumbuhan dari pengeluaran rutin tidak signifikan.

2. Pada tingkat sektoral, pengeluaran investasi pemerintah dan total pengeluaran dalam sektor pendidikan adalah satu-satunya yang tetap berasosiasi secara signifikan dengan pertumbuhan untuk keseluruhan analisis.

Di dalam paper ini, akan digunakan model tersebut dan akan dimodifikasi untuk melihat bagaimana pengaruh dari pertumbuhan pengeluaran pemerintah sektoral di masing-masing propinsi-propinsi di Indonesia terhadap pertumbuhan ekonomi di propinsi tersebut. Akan tetapi di dalam paper ini, karena kami hanya menggunakan negara Indonesia saja, maka kami tidak menggunakan variabel kebijakan moneter, karena di Indonesia, hanya Bank Indonesia yang dapat mengeluarkan kebijakan moneter, yang dapat mempengaruhi variabel moneter. Oleh karena itu, kami tidak memperoleh data M2 (broad money) untuk masing-masing propinsi. Selain itu, kami juga tidak menggunakan model dengan kendala anggaran pemerintah, karena keterbatasan waktu yang kami miliki. Dengan demikian, di dalam paper ini, kami hanya menggunakan model pertama saja, dari 3 model yang dibangun oleh Niloy Bose et al (2007).

\section{Model Penelitian}

Di dalam paper ini, akan digunakan model yang dibangun dari paper yang berjudul 'Public Expenditure and Economic Growth: A Disaggregated Analysis for Developing Countries' yang ditulis oleh Niloy Bose, M. Emranul Haque dan Denise R. Osborn. Di dalam paper tersebut mereka meneliti dampak dari pengeluaran pemerintah untuk tiga puluh negara sedang berkembang dari tahun $1970 \mathrm{~s} / \mathrm{d}$ 1990, dengan fokus pada beberapa sektor pengeluaran, yaitu sektor pertahanan, pendidikan, kesehatan, pertanian, transportasi dan komunikasi, dan manufacturing. Hal ini dikarenakan hanya ke 6 sektor tersebut saja yang berpengaruh secara signifikan.

Di dalam penelitian ini, menggunakan 17 sektor yang ada di dalam realisasi anggaran dan pendapatan belanja daerah di masing-masing propinsi. Adapun ke 17 sektor tersebut adalah: (1) Sektor Industri; (2) Sektor Pertanian dan Pengairan ; (3) Sektor Tenaga Kerja; (4) Sektor Perdagangan, Pengembangan Usaha Daerah, Keuangan daerah dan Koperasi; (5) Sektor Transportasi dan Perhubungan; (6) Sektor Pertambangan dan Energi; (7) Sektor Pembangunan Daerah dan Pemukiman ; (8) Sektor Lingkungan Hidup dan Tata ruang ; (9) Sektor Pendidikan, Kebudayaan Nasional, Kepercayaan Terhadap Tuhan Yang Maha Esa, Pemuda dan Olah Raga ; (10) Sektor Kependudukan, Kesehatan, Kesejahteraan Sosial, Peranan Wanita, Anak dan Remaja ; (11) Sektor Perumahan dan Pemukiman ; (12) Sektor Agama ; (13) Sektor Ilmu Pengetahuan dan Teknologi ; (14) Sektor Hukum; (15) Sektor Aparatur 
Pemerintah dan Pengawasan ; (16) Sektor Politik, Penerangan, Komunikasi dan Media Massa ; (17) Sektor Keamanan dan Ketertiban Umum.

Ke 17 sektor tersebut akan diregresi satu persatu dengan menggunakan metode panel seemingly unrelated regression (SURE). Hal ini dilakukan karena metode tersebut akan menghasilkan estimator yang efisien walaupun terdapat korelasi antar disturbance term di dalam suatu sistem persamaan(Zellner 1962). Dengan demikian, di dalam penelitian ini disturbance term, untuk propinsi i pada periode yang satu, dapat berkorelasi dengan disturbance term untuk propinsi yang sama pada periode yang berbeda. Hal ini terjadi karena di dalam realisasi anggaran dan pendapatan belanja daerah, terdapat pos Bagian Sisa Lebih Perhitungan Anggaran Tahun Lalu, sehingga kemungkinan akan terdapat korelasi antara disturbance term antar periode di dalam propinsi yang sama. Dengan demikian dapat disimpulkan bahwa metode ini digunakan untuk mengantisipasi hal tersebut. Adapun model yang digunakan di dalam penelitian ini ialah:

$$
G R_{i t}=\beta_{0 t}+\sum_{j=1}^{n} \beta_{j}^{I} I_{j, i t}+\beta^{M} M_{i t}+u_{i t}
$$

Kelompok variabel I terdiri dari variabel-ariabel yang biasanya muncul sebagai conditioning variables di dalam model regresi pertumbuhan, di mana di dalam penelitian ini yang akan digunakan adalah pengeluaran pemerintah rutin, tax revenue, investasi swasta, tingkat harapan hidup dan initial PDB perkapita. Sedangkan kelompok variabel $\mathrm{M}$ ialah kelompok dari variabel pengeluaran pemerintah yang menjadi interest di dalam penelitian ini yaitu pengeluaran pembangunan pemerintah di 17 sektor tersebut. Sebenarnya di dalam model aslinya, terdapat variabel broad money (M2) dan ketidakstabilan politik, untuk melihat bagaimanakah pengaruh dari pengeluaran pemerintah terhadap pertumbuhan ekonomi. Akan tetapi karena yang dijadikan obyek penelitian di dalam paper ini ialah tingkat propinsi di Indonesia, maka baik ketidakstabilan politik maupun broad money (M2) tidak digunakan karena dianggap memiliki nilai yang sama untuk seluruh propinsi di Indonesia. Walaupun masih terbuka peluang untuk melakukan instrumentasi terhadap ke dua variabel tersebut. Akan tetapi dalam penelitian ini kami belum melakukan hal tersebut karena adanya keterbatasan waktu.

Adapun variabel instrumen yang mungkin dapat digunakan untuk variabel broad money (M2) ialah jumlah simpanan rupiah di masing-masing propinsi, di mana datanya telah tersedia di website Bank Indonesia. Sedangkan untuk ketidakstabilanpolitik mungkin dapat diinstrumentasi dengan ada atau tidaknya pemilihan kepala daerah pada tahun tersebut, karena pemilihan kepala daerah akan meningkatkan eskalasi politik di daerah tersebut, dan dalam beberapa kasus tertentu menyebabkan terjadi konflik antar masyarakat, sehingga menyebabkan ketidakstabilan politik.

Dengan demikian, data yang digunakan di dalam penelitian ini ialah data pengeluaran pemerintah baik pengeluaran rutin maupun pengeluaran pembangunan (baik pengeluaran total maupun sektoral) dari realisasi Anggaran Pendapatan dan Belanja Daerah tingkat 1 untuk periode dari tahun 1990 s/d 2010. Selain data pengeluaran pemerintah, juga akan digunakan data Produk Domestik Regional Bruto 
(PDRB) perkapita, jumlah populasi, tingkat harapan hidup, investasi swasta, dan tax revenue. Keseluruhan variabel tersebut akan diklasifikasikan ke dalam dua kelompok data yaitu kelompok I, dan M, seperti yang telah dijelaskan di atas. Keseluruhan variabel ini akan dihitung dalam persentase PDRB.

Selain itu, dalamp penelitian juga memasukkan variabel boneka ke dalam model, karena selama periode penelitian terjadi krisis ekonomi yang cukup besar sehingga kemungkinan menghasilkan perubahan struktur perekonomian yang cukup signifikan. Untuk melakukan penghitungan dengan model panel SURE, pertamatama yang dilakukan ialah melakukan panel set up data, kemudian dilakukan regresi satu persatu untuk keseluruhan variabel yang masuk dalam kelompok $\mathrm{M}$, dengan mengontrol variabel-variabel yang masuk dalam kelompok I. Hal ini dilakukan untuk melihat apakah variabel dalam kelompok $M$ tersebut berasosiasi secara signifikan atau tidak dengan pertumbuhan ekonomi, setelah kita mengontrol conditioning variable yang ada di dalam kelompok I. Oleh karena adanya keterbatasan data, maka dalam penelitian ini tidak melakukan robustness check untuk mengontrol distorsi pasar dan adverse effect dari guncangan perdagangan yang terjadi di beberapa propinsi selama periode penelitian.

Data yang digunakan di dalam penelitian ini ialah data pengeluaran pemerintah baik pengeluaran rutin maupun pengeluaran pembangunan sektoral dari realisasi Anggaran Pendapatan dan Belanja Daerah tingkat 1 untuk periode dari tahun $1990 \mathrm{~s} / \mathrm{d}$ 2010. Selama periode penelitian, terdapat perubahan pencatatan realisasi Anggaran Pendapatan dan Belanja Daerah oleh pemerintah daerah, sehingga perlu dilakukan sinkronisasi terlebih dahulu.

Adapun salah satu perubahan yang dilakukan pemerintah ialah mengenai periode waktu pencatatannya. Untuk data realisasi Anggaran Pendapatan dan Belanja Daerah sebelum tahun 2000, periode pencatatannya didasarkan pada tahun anggaran, sehingga dimulai pada tanggal 1 April dan berakhir tanggal 31 Maret. Akan tetapi mulai tahun 2001, periode pencatatan dilakukan berdasarkan tahun berjalan, sehingga dimulai tanggal 1 Januari dan berakhir tanggal 31 Desember. Khusus untuk tahun 2000, periode pencatatannya adalah dimulai tanggal 1 April 2000 sampai dengan 31 Desember 2000, sehingga hanya mencatat realisasi selama 9 bulan saja. Oleh karena itu, untuk keseluruhan periode penelitian perlu diubah terlebih dahulu menjadi tahun berjalan agar sesuai dengan periode pencatatan dalam Produk Domestik Bruto (PDB).

Skenario yang lakukan untuk melakukan penyamaan periode pencatatan tersebut dengan mengasumsikan bahwa keseluruhan realisasi pajak dan pengeluaran rutin, sama besar untuk setiap bulannya, sedangkan untuk realisasi pembangunan sektoral akan diberi bobot yaitu 40\% untuk triwulan terakhir dari tahun anggaran. Hal ini dilakukan berdasarkan informasi yang didapatkan dari data Pemerintah daerah, bahwa penyerapan anggaran pengeluaran pembangunan pada triwulan terakhir dalam tahun anggaran tertentu lebih tinggi bila dibandingkan dengan tiga triwulan pertama.

Selain masalah periode pencatatan, pemerintah juga melakukan perubahan yang cukup mendasar dalam pencatatan realisasi pengeluaran daerah dengan 
diterbitkannya Keputusan Menteri Dalam Negri nomor 29 tahun 2002. Dengan adanya keputusan tersebut, pos penerimaan daerah dan pengeluaran rutin daerah relatif sama, sehingga tidak menimbulkan masalah, akan tetapi untuk pengeluaran pembangunan, keputusan ini menjadi masalah karena pengeluaran pembangunan yang dilakukan tidak dicatat per masing-masing sektor, seperti yang dilakukan sebelum keluarnya keputusan tersebut.

Pada tahun 2006, pemerintah menerbitkan Peraturan Menteri Dalam Negeri No. 13 tahun 2006, mengenai Pedoman Pengelolaan Keuangan Daerah yang melampirkan klasifikasi belanja menurut fungsi, yang mirip dengan klasifikasi pengeluaran pembangunan sektoral, sehingga kami akan menggunakan klasifikasi tersebut sebagai dasar pembagian pengeluaran pembangunan berdasarkan sektoral. Oleh karena ada jeda antara Keputusan Menteri Dalam Negeri No. 29 tahun 2002 dengan Peraturan Menteri Dalam Negeri No. 13 tahun 2006, maka perlu dilakukan disagregasi data pengeluaran pembangunan ke dalam sektoral. Untuk melakukan hal tersebut, kami akan mengasumsikan bahwa tidak terjadi perubahan persentase sektoral terhadap total pengeluaran pembangunan di masing-masing propinsi dari tahun 2002.

Dengan demikian untuk realisasi APBD pengeluaran pembangunan sektoral untuk tahun 2003, 2004, 2005 dan 2006, persentase sektoral-nya sama dengan tahun 2002. Sedangkan untuk tahun 2007 ke atas, kami akan melakukan sinkronisasi dengan klasifikasi pengeluaran pembangunan sektoral sebelum keluarnya Keputusan Menteri Dalam Negeri No. 29 tahun 2002.

Selain masalah pencatatan realisasi APBD, perubahan mendasar juga terjadi pada karakteristik propinsi yang ada di Indonesia. Pada tanggal 30 Agustus 1999, diadakan referendum di Propinsi Timor-Timur untuk menentukan apakah tetap menjadi bagian dari Republik Indonesia ataukah lepas menjadi negara yang berdiri sendiri. Adapun hasil referendum tersebut, yang diumumkan oleh Sekjen PBB Kofi Annan pada tanggal 4 September 1999, 79\% penduduk Timor-Timur yang berhak mengikuti referendum, menghendaki agar Propinsi Timor-Timur lepas dari Republik Indonesia, sehingga sejak saat itu, cakupan wilayah geografis Indonesia tidak meliputi wilayah tersebut. Oleh karena itu, Propinsi Timor-Timur dihilangkan dari keseluruhan periode penelitian.

Adanya UU no. 22 tahun 1999, beberapa propinsi di Indonesia juga mengalami pemekaran wilayah. Adapun propinsi-propinsi yang mengalami pemekaran wilayah adalah sebagai berikut: (1) Propinsi Sumatera Selatan dimekarkan menjadi 2 propinsi yaitu Propinsi Sumatera Selatan dan Propinsi Bangka Belitung; (2) Propinsi Jawa Barat dimekarkan menjadi 2 propinsi yaitu Propinsi Jawa Barat dan Propinsi Banten ; (3) Propinsi Sulawesi Utara dimekarkan menjadi 2 propinsi yaitu Propinsi Sulawesi Utara dan Propinsi Gorontalo ; (4) Propinsi Maluku dimekarkan menjadi 2 propinsi yaitu Propinsi Maluku dan Propinsi Maluku Utara ; (5) Propinsi Sulawesi Selatan dimekarkan menjadi 2 propinsi yaitu Propinsi Sulawesi Selatan dan Propinsi Sulawesi Barat.

Sementara itu, disamping pemekaran di tingkat propinsi, pemekaran wilayah juga terjadi di tingkat kabupaten/kota, namun karena obyek penelitian ini adalah tingkat propinsi, dimana tidak memperhitungkan pemekaran wilayah di tingkat 2, 
sebagai dasar sinkronisasi data. Selain data realisasi Anggaran Pendapatan dan Belanja Daerah yang perlu disinkronkan, penghitungan PDB riil dan investasi swasta juga perlu diperhatikan karena selama periode penelitian menggunakan tahun dasar yang berbeda. Oleh karena itu, perlu disamakan terlebih dulu tahun dasarnya agar dapat dilakukan penghitungan pertumbuhan ekonomi secara benar. Keseluruhan data yang telah disusun tersebut kemudian diolah dengan menggunakan program STATA versi 11.0.

\section{Hasil Penelitian}

Setelah dilakukan set up data panel, kemudian dilakukan penghitungan regresi dengan menggunakan metode panel SURE, di mana hasilnya untuk masing-masing sektor akan dibahas di bawah ini.

\subsection{Sektor Industri}

Berdasarkan hasil penghitungan yang telah dilakukan, maka didapatkan hasil sebagai berikut:

Tabel 3.1. Hasil Penghitungan Seemingly Unrelated Regression untuk Sektor Industri

\begin{tabular}{|c|c|}
\hline Keterangan & $\begin{array}{l}\text { Ln PDRB Per } \\
\text { Kapita }\end{array}$ \\
\hline Krisis Ekonomi & $\begin{array}{l}-0.0864^{*} \\
-(0.0517)\end{array}$ \\
\hline Penerimaan Pemerintah Rutin & $\begin{array}{c}-12.3101^{* * *} \\
(-4.7433)\end{array}$ \\
\hline Penerimaan Pajak (Tax Revenue) & $\begin{array}{l}0.5014^{* * *} \\
(-0.1139)\end{array}$ \\
\hline Investasi Daerah & $\begin{array}{l}0.8899^{* * *} \\
-(0.1403)\end{array}$ \\
\hline Initial PDRB & $\begin{array}{c}0.0014^{* * *} \\
(0.0057)\end{array}$ \\
\hline Tingkat Harapan Hidup & $\begin{array}{l}3.9622^{* * *} \\
(-0.3339)\end{array}$ \\
\hline Pengeluaran Pembangunan Pemerintah Sektor Industri & $\begin{array}{l}-0.9396^{*} \\
-(0.3339)\end{array}$ \\
\hline _cons & $\begin{array}{l}12.5568 \\
(-1.3837)\end{array}$ \\
\hline R-sq & 0.3613 \\
\hline Obs & 546 \\
\hline
\end{tabular}

Sumber : Hasil Perhitungan

Pada Tabel 3.1, terlihat bahwa variabel pengeluaran pembangunan pemerintah di sektor industri berasosiasi secara negatif dengan taraf signifikan $10 \%$ terhadap pertumbuhan ekonomi. Hal ini cukup menarik karena ternyata pengeluaran pembangunan sektor industri berasosiasi secara negatif dengan pertumbuhan 
Bayu Kharisma, dan Adji Pratikto. Pengeluaran Pemerintah dan Pertumbuhan ......

ekonomi, yang berarti berbeda dengan temuan dari Niloy Bose dkk, yang menghasilkan kesimpulan bahwa sektor industri tidak berpengaruh secara signifikan dengan pertumbuhan ekonomi. Selain itu, variabel boneka d1 juga berpengaruh secara negatif dengan taraf signifikansi 10\%, yang berarti bahwa, dalam melihat dampak dari pengeluaran pembangunan sektor industri terhadap pertumbuhan ekonomi, dengan kondisi ceteris paribus, pertumbuhan ekonomi setelah tahun 1998 akan lebih rendah bila dibandingkan dengan pertumbuhan ekonomi sebelum tahun 1998.

\subsection{Sektor Pertanian dan Pengairan}

Adapun hasil penghitungan sektor pertanian dan pengairan adalah sebagai berikut:

Tabel. 3.2. Hasil Perhitungan Seemingly Unrelated Regression Pembangunan untuk Sektor Pertanian dan Pengairan

\begin{tabular}{|c|c|}
\hline Keterangan & $\begin{array}{c}\text { Ln PDRB Per } \\
\text { Kapita }\end{array}$ \\
\hline Krisis Ekonomi & $\begin{array}{l}-0.0555 \\
(0.0522)\end{array}$ \\
\hline Penerimaan Pemerintah Rutin & $\begin{array}{c}-9.8703^{* *} \\
(4.7433)\end{array}$ \\
\hline Penerimaan Pajak (Tax Revenue) & $\begin{array}{c}0.5374^{* * *} \\
(0.1137) \\
\end{array}$ \\
\hline Investasi Daerah & $\begin{array}{l}0.92288^{* * *} \\
(0.139935)\end{array}$ \\
\hline Initial PDRB & $\begin{array}{c}-0.0011^{* *} \\
(0.0057) \\
\end{array}$ \\
\hline Tingkat Harapan Hidup & $\begin{array}{c}3.8307^{* * *} \\
(0.3338) \\
\end{array}$ \\
\hline Pengeluaran Pembangunan Pemerintah sektor pertanian dan pengairan & $\begin{array}{c}-0.4186^{* * *} \\
(0.1191) \\
\end{array}$ \\
\hline -cons & $\begin{array}{c}0.1308 \\
(0.1383) \\
\end{array}$ \\
\hline R-sq & 0.3715 \\
\hline Obs & 546 \\
\hline
\end{tabular}

Sumber : Hasil Perhitungan

Dalam Tabel 3.2. di atas terlihat bahwa sama seperti di sektor industri, sektor pertanian dan pengairan juga berpengaruh negatif terhadap pertumbuhan ekonomi. Hal ini juga cukup menarik karena ternyata pengeluaran pembangunan di ke dua sektor ini malahan menghambat pertumbuhan ekonomi. Akan tetapi tidak seperti di sektor industri, variabel boneka krisis ekoonmi tidak berpengaruh secara signifikan terhadap pertumbuhan ekonomi. Selain itu, yang cukup menarik lainnya adalah pengeluaran rutin pemerintah berpengaruh secara negatif terhadap pertumbuhan ekonomi, yang ini juga berbeda dengan temuan dari Niloy Bose et al (2007).

\subsection{Sektor Tenaga Kerja}

Adapun hasil penghitungan sektor tenaga kerja adalah sebagai berikut: 
Tabel. 3.3. Hasil Penghitungan Seemingly Unrelated Regression untuk Sektor Tenaga

\begin{tabular}{|c|c|}
\hline \multicolumn{2}{|l|}{ Kerja } \\
\hline Keterangan & $\begin{array}{l}\text { Ln PDRB Per } \\
\text { Kapita }\end{array}$ \\
\hline Krisis Ekonomi & $\begin{array}{c}-0.0939^{* *} \\
(0.0517)\end{array}$ \\
\hline Penerimaan Pemerintah Rutin & $\begin{array}{c}-15.0363^{* *} \\
(4.9201)\end{array}$ \\
\hline Penerimaan Pajak (Tax Revenue) & $\begin{array}{c}0.4839 * * * \\
(0.1154)\end{array}$ \\
\hline Investasi Daerah & $\begin{array}{c}0.8927^{* * *} \\
(0.1413)\end{array}$ \\
\hline Initial PDRB & $\begin{array}{c}-0.0012^{* *} \\
(0.0057)\end{array}$ \\
\hline Tingkat Harapan Hidup & $\begin{array}{c}4.0425^{* * *} \\
(0.3321)\end{array}$ \\
\hline Pengeluaran Pembangunan Pemerintah sektor Tenaga Kerja & $\begin{array}{c}0.1562 \\
(0.8646)\end{array}$ \\
\hline _cons & $\begin{array}{l}12.2220 \\
(0.1376)\end{array}$ \\
\hline R-sq & 0.3573 \\
\hline chi2 & 299.67 \\
\hline Obs & 546 \\
\hline
\end{tabular}

Sumber : Hasil Perhitungan

Pada Tabel 3.3. di atas, pengeluaran pembangunan di sektor tenaga kerja tidak berpengaruh secara signifikan terhadap pertumbuhan ekonomi.

\subsection{Sektor Perdagangan, Pengembangan Usaha Daerah, Keuangan daerah dan Koperasi}

Adapun hasil penghitungan sektor Perdagangan, Pengembangan Usaha Daerah, Keuangan daerah dan Koperasi adalah sebagai berikut:

Tabel. 3.4. Hasil Penghitungan Seemingly Unrelated Regression untuk Sektor Perdagangan, Pengembangan Usaha Daerah, Keuangan daerah dan Koperasi

\begin{tabular}{|l|c|}
\hline \multicolumn{1}{c|}{ Keterangan } & Ln PDRB Per \\
Kapita \\
\hline Krisis Ekonomi & -0.0079 \\
& $(0.0530)$ \\
\hline Penerimaan Pemerintah Rutin & $-13.2812^{* * *}$ \\
\hline Penerimaan Pajak (Tax Revenue) & $(4.7442)$ \\
\hline Investasi Daerah & $0.5421^{* * *}$ \\
& $(0.1236)$ \\
\hline Initial PDRB & $0.8938^{* * *}$ \\
\hline
\end{tabular}


Bayu Kharisma, dan Adji Pratikto. Pengeluaran Pemerintah dan Pertumbuhan ......

\begin{tabular}{|l|c|}
\hline & $(0.0057)$ \\
\hline Tingkat Harapan Hidup & $3.9581^{* * *}$ \\
& $(0.3390)$ \\
\hline Pengeluaran Pembangunan Pemerintah sektor Perdagangan, Pengembangan & -0.0114 \\
Usaha Daerah, Keuangan daerah dan Koperasi & $(0.0951)$ \\
\hline _cons & 12.5692 \\
& $(1.4045)$ \\
\hline R-sq & 0.3589 \\
\hline chi2 & 301.90 \\
\hline
\end{tabular}

Sumber : Hasil Perhitungan

Sama seperti sektor tenaga kerja, pengeluaran pembangunan sektor perdagangan, pengembangan usaha daerah, keuangan daerah dan koperasi juga tidak perpengaruh secara signifikan.

\subsection{Sektor Transportasi dan Perhubungan}

Adapun hasil penghitungan sektor transportasi dan perhubungan adalah sebagai berikut:

Tabel. 3.5. Hasil Penghitungan Seemingly Unrelated Regression untuk Sektor Transportasi dan Perhubungan

\begin{tabular}{|l|c|}
\hline \multicolumn{1}{c|}{ Keterangan } & $\begin{array}{c}\text { Ln PDRB Per } \\
\text { Kapita }\end{array}$ \\
\hline Krisis Ekonomi & $-0.0938^{*}$ \\
& $(0.0506)$ \\
\hline Penerimaan Pemerintah Rutin & -4.4448 \\
& $(4.9300)$ \\
\hline Penerimaan Pajak (Tax Revenue) & $0.41971^{* * *}$ \\
& $(0.1123)$ \\
\hline Investasi Daerah & $0.96276^{* * *}$ \\
& $(0.1390)$ \\
\hline Initial PDRB & $-0.013^{* *}$ \\
& $(0.0056)$ \\
\hline Tingkat Harapan Hidup & $3.6077^{* * *}$ \\
& $(0.3369)$ \\
\hline Pengeluaran Pembangunan Pemerintah sektor transportasi dan perhubungan & $-0.68221^{* * *}$ \\
& $0.1395)$ \\
\hline cons & $14.0771^{* * *}$ \\
\hline R-sq & $(1.3993)$ \\
\hline chi2 & 0.3842 \\
\hline Obs & 336.70 \\
\hline
\end{tabular}

Sumber : Hasil Perhitungan

Pada Tabel 3.5, terlihat bahwa pengeluaran pembangunan sektor transportasi dan perhubungan berpengaruh negatif dengan taraf signifikansi 1\%. Hal ini berarti sama seperti pengeluaran pembangunan di sektor industri dan pertanian dan pengairan, yang juga sama-sama berpengaruh negatif terhadap pertumbuhan 
ekonomi. Hal ini agak mengejutkan karena pengaruhnya adalah negatif, karena kalau dilihat dari kondisi infrastruktur di Indonesia, sebenarnya masih sangat dibutuhkan pembangunan infrastruktur yang lebih baik. Akan tetapi hal ini kemungkinan terjadi karena besarnya korupsi yang terjadi di sektor tersebut, karena dari beberapa kasus yang terjadi, seperti runtuhnya jembatan dan sering rusaknya jalan, mengindikasikan hal tersebut.

\subsection{Sektor Pertambangan dan Energi}

Adapun hasil penghitungan untuk pengeluaran pembangunan sektor pertambangan dan energi adalah sebagai berikut:

Tabel. 3.6. Hasil Penghitungan Seemingly Unrelated Regression untuk Sektor Pertambangan dan Energi

\begin{tabular}{|l|c|}
\hline \multicolumn{1}{c|}{ Keterangan } & $\begin{array}{c}\text { Ln PDRB Per } \\
\text { Kapita }\end{array}$ \\
\hline Krisis Ekonomi & $-0.0939^{*}$ \\
& $(0.0517)$ \\
\hline Penerimaan Pemerintah Rutin & -14.2402 \\
& $(5.4543)$ \\
\hline Penerimaan Pajak (Tax Revenue) & $0.4788^{* * *}$ \\
& $(0.1159)$ \\
\hline Investasi Daerah & $0.8973^{* * *}$ \\
& $(0.1423)$ \\
\hline Initial PDRB & $-0.0012^{* *}$ \\
& $(0.0059)$ \\
\hline Tingkat Harapan Hidup & $4.0384^{* *}$ \\
& $(0.3324)$ \\
\hline Pengeluaran Pembangunan Pemerintah Sektor Pertambangan dan Energi & -0.1785 \\
& $(0.7129)$ \\
\hline cons & $12.2383^{* * *}$ \\
& $(1.3776)$ \\
\hline R-sq & 0.3573 \\
\hline chi2 & 299.76 \\
\hline Obs & 546 \\
\hline
\end{tabular}

Sumber : Hasil Perhitungan

Dengan demikian, sama seperti sektor tenaga kerja dan sektor perdagangan, pengeluaran sektor pertambangan dan energi juga tidak berpengaruh scara signifikan terhadap pertumbuhan ekonomi.

\subsection{Sektor Pembangunan daerah dan Pemukiman}

Adapun hasil penghitungan untuk pengeluaran pembangunan sektor pembangunan daerah dan pemukiman adalah sebagai berikut: 
Bayu Kharisma, dan Adji Pratikto. Pengeluaran Pemerintah dan Pertumbuhan ......

Tabel. 3.7. Hasil Penghitungan Seemingly Unrelated Regression Sektor Pembangunan Daerah dan Pemukiman

\begin{tabular}{|c|c|}
\hline Keterangan & $\begin{array}{l}\text { Ln PDRB Per } \\
\text { Kapita }\end{array}$ \\
\hline Krisis Ekonomi & $\begin{array}{l}-0.0878^{*} \\
(0.0517)\end{array}$ \\
\hline Penerimaan Pemerintah Rutin & $\begin{array}{l}-0.1246^{*} \\
(0.4867)\end{array}$ \\
\hline Penerimaan Pajak (Tax Revenue) & $\begin{array}{c}0.4824^{* * *} \\
(0.1136)\end{array}$ \\
\hline Investasi Daerah & $\begin{array}{l}0.897^{* * *} \\
(0.1410)\end{array}$ \\
\hline Initial PDRB & $\begin{array}{c}-0.0011^{* *} \\
(0.0057)\end{array}$ \\
\hline Tingkat Harapan Hidup & $\begin{array}{c}4.0005^{* * *} \\
(0.3327)\end{array}$ \\
\hline $\begin{array}{l}\text { Pengeluaran Pembangunan Pemerintah Sektor Pembangunan Daerah dan } \\
\text { Pemukiman }\end{array}$ & $\begin{array}{l}-0.7690 \\
(0.5462)\end{array}$ \\
\hline _cons & $\begin{array}{c}12.3937^{* * *} \\
(1.3789)\end{array}$ \\
\hline R-sq & 0.3596 \\
\hline chi2 & 302.74 \\
\hline $\mathrm{P}$ & 0.0000 \\
\hline Obs & 546 \\
\hline
\end{tabular}

Sumber : Hasil Perhitungan

Pada Tabel 3.5. di atas terlihat bahwa pengeluaran pembangunan sektor pembangunan daerah dan pemukiman tidak berpengaruh secara signifikan terhadap pertumbuhan ekonomi.

\subsection{Sektor Lingkungan Hidup dan Tata ruang}

Adapun hasil penghitungan untuk pengeluaran pembangunan sektor lingkungan hidup dan tata ruang adalah sebagai berikut:

Tabel. 3.8. Hasil Penghitungan Seemingly Unrelated Regression Sektor Lingkungan Hidup dan Tata ruang

\begin{tabular}{|l|c|}
\hline \multicolumn{1}{|c|}{ Keterangan } & $\begin{array}{c}\text { Ln PDRB Per } \\
\text { Kapita }\end{array}$ \\
\hline Krisis Ekonomi & $-0.0948^{*}$ \\
& $(0.05058)$ \\
\hline Penerimaan Pemerintah Rutin & -4.4447 \\
& $(4.9301)$ \\
\hline Penerimaan Pajak (Tax Revenue) & $0.4197^{* * *}$ \\
\hline Investasi Daerah & $(0.1123)$ \\
\hline Initial PDRB & $0.9628^{* * *}$ \\
& $(0.1389)$ \\
\hline
\end{tabular}


E-Jurnal Ekonomi dan Bisnis Universitas Udayana 8.1 (2019): 1-22

\begin{tabular}{|l|c|}
\hline Tingkat Harapan Hidup & $3.6077^{* * *}$ \\
& $(0.3370)$ \\
\hline Pengeluaran Pembangunan Pemerintah sektor transportasi dan perhubungan & $-0.6822^{* * *}$ \\
& $(0.1395)$ \\
\hline Cons & $14.0771^{* *}$ \\
& $(1.3993)$ \\
\hline R-sq & 0.3842 \\
\hline chi2 & 336.70 \\
\hline Obs & 546 \\
\hline
\end{tabular}

Sumber : Hasil Perhitungan

Pengeluaran pembangunan sektor lingkungan hidup dan tata ruang berpengaruh negatif dengan taraf signifikansi 1\%. Hal ini cukup menarik, karena sampai sejauh ini, hampir seluruh pengeluaran pembangunan berpengaruh secara negatif terhadap pertumbuhan ekonomi. Lebih jelasnya dapat dilihat paa Tabel 3.8.

\subsection{Sektor Pendidikan, Kebudayaan Nasional, Kepercayaan Terhadap Tuhan Yang Maha Esa, Pemuda Dan Olah Raga}

Adapun hasil penghitungan untuk pengeluaran pembangunan sektor Pendidikan, Kebudayaan Nasional, Kepercayaan Terhadap Tuhan Yang Maha Esa, Pemuda dan Olah Raga adalah sebagai berikut:

Tabel. 3.9. Hasil Penghitungan Seemingly Unrelated Regression Sektor Pendidikan, Kebudayaan Nasional, Kepercayaan Terhadap Tuhan YME, Pemuda Dan Olah Raga

\begin{tabular}{|l|c|}
\hline \multicolumn{1}{|c|}{ Keterangan } & $\begin{array}{c}\text { Ln PDRB Per } \\
\text { Kapita }\end{array}$ \\
\hline Krisis Ekonomi & -0.1008 \\
& $(0.0518)$ \\
\hline Penerimaan Pemerintah Rutin & -16.6487 \\
& $(4.7011)$ \\
\hline Penerimaan Pajak (Tax Revenue) & $0.45018^{* * *}$ \\
& $(0.1168)$ \\
\hline Investasi Daerah & $0.8909^{* * *}$ \\
& $(0.1410)$ \\
\hline Initial PDRB & $-0.0012^{* *}$ \\
& $(0.0057)$ \\
\hline Tingkat Harapan Hidup & $4.065334^{* * *}$ \\
& $0.3320211)$ \\
\hline Pengeluaran Pembangunan Pemerintah sektor Pendidikan, Kebudayaan Nasional, & 0.5472 \\
Kepercayaan Terhadap Tuhan Yang Maha Esa, Pemuda Dan Olah Raga & $(0.4276)$ \\
\hline cons & $12.1296^{* * *}$ \\
& $(1.3758)$ \\
\hline R-sq & 0.3592 \\
\hline Obsi2 & 302.20 \\
\hline Sub & 546 \\
\hline
\end{tabular}

Sumber : Hasil Perhitungan 
Pada Tabel 3.9. di atas terlihat bahwa pengeluaran pembangunan sektor pendidikan tidak berpengaruh secara signifikan terhadap pertumbuhan ekonomi. Akan tetapi yang cukup menarik di sini ialah bahwa pengaruhnya adalah positif walaupun tidak signifikan. Hal ini sangat berbeda dengan sektor-sektor sebelumnya yang selalu menghasilkan kesimpulan yang sebaliknya.

\subsection{Sektor Kependudukan, Kesehatan, Kesejahteraan Sosial, Peranan Wanita, Anak dan Remaja}

Adapun hasil penghitungan untuk pengeluaran pembangunan sektor Kependudukan, Kesehatan, Kesejahteraan Sosial, Peranan Wanita, Anak dan Remaja adalah sebagai berikut:

Tabel. 3.10. Hasil Penghitungan Seemingly Unrelated Regression untuk Sektor Kependudukan, Kesehatan, Kesejahteraan Sosial, Peranan Wanita, Anak dan Remaja

\begin{tabular}{|c|c|}
\hline Keterangan & $\begin{array}{l}\text { Ln PDRB Per } \\
\text { Kapita }\end{array}$ \\
\hline Krisis Ekonomi & $\begin{array}{l}-0.1043^{*} \\
(0.0537)\end{array}$ \\
\hline Penerimaan Pemerintah Rutin & $\begin{array}{r}-16.7159 \\
(0.5152) \\
\end{array}$ \\
\hline Penerimaan Pajak (Tax Revenue) & $\begin{array}{c}0.4873^{* * *} \\
(0.1139)\end{array}$ \\
\hline Investasi Daerah & $\begin{array}{c}0.8947^{* * *} \\
(0.1412)\end{array}$ \\
\hline Initial PDRB & $\begin{array}{c}-0.0012^{* *} \\
(0.0057)\end{array}$ \\
\hline Tingkat Harapan Hidup & $\begin{array}{c}4.0818^{* * *} \\
(0.3366)\end{array}$ \\
\hline $\begin{array}{l}\text { Pengeluaran Pembangunan Pemerintah Sektor Kependudukan, Kesehatan, } \\
\text { Kesejahteraan Sosial, Peranan Wanita, Anak dan Remaja }\end{array}$ & $\begin{array}{c}0.3431 \\
(0.4925) \\
\end{array}$ \\
\hline _cons & $\begin{array}{c}12.0642^{* * *} \\
(1.3937)\end{array}$ \\
\hline R-sq & 0.3578 \\
\hline chi2 & 300.42 \\
\hline Obs & 546 \\
\hline
\end{tabular}

Sumber : Hasil Perhitungan

Dalam Tabel 3.10 di atas terlihat bahwa pengeluaran pembangunan sektor kesehatan juga tidak berpengaruh secara signifikan terhadap pertumbuhan ekonomi. Akan tetapi yang cukup menarik di sini ialah bahwa sama seperti sektor pendidikan, pengaruhnya adalah positif walaupun tidak signifikan. Dengan demikian, pengeluaran pembangunan yang berkaitan dengan pembangunan sumberdaya manusia mempunyai pengaruh yang positif walaupun tidak signifikan.

\subsection{Sektor Perumahan dan Pemukiman}

Adapun hasil penghitungan untuk pengeluaran pembangunan sektor Perumahan dan Pemukiman adalah sebagai berikut: 
Tabel. 3.11. Hasil Penghitungan Seemingly Unrelated Regression untuk Sektor Perumahan dan Pemukiman

\begin{tabular}{|l|c|}
\hline \multicolumn{1}{|c|}{ Keterangan } & $\begin{array}{c}\text { Ln PDRB Per } \\
\text { Kapita }\end{array}$ \\
\hline Krisis Ekonomi & $-0.0943^{*}$ \\
& $(0.0516)$ \\
\hline Penerimaan Pemerintah Rutin & $-16.2297^{* * *}$ \\
& $(5.1253)$ \\
\hline Penerimaan Pajak (Tax Revenue) & $0.4941^{* * *}$ \\
& $(0.1155)$ \\
\hline Investasi Daerah & $897497.1^{* * *}$ \\
& $(0.1415)$ \\
\hline Initial PDRB & $-0.0012^{* *}$ \\
& $(0.0057)$ \\
\hline Tingkat Harapan Hidup & $4.0293^{* * *}$ \\
& $(0.3330)$ \\
\hline Pengeluaran Pembangunan Pemerintah Sektor Perumahan dan Pemukiman & 0.3431 \\
\hline cons & $(0.4925)$ \\
\hline R-sq & $12.2786^{* * *}$ \\
\hline chi2 & $(1.3802)$ \\
\hline P & 0.3576 \\
\hline Obs & 300.07 \\
\hline
\end{tabular}

Sumber : Hasil Perhitungan

Sama seperti estimasi tiga sektor sebelumnya, pengeluaran pembangunan sektor perumahan dan pemukiman juga tidak berpengaruh secara signifikan terhadap pertumbuhan ekonomi.

\subsection{Sektor Agama}

Adapun hasil penghitungan untuk pengeluaran pembangunan sektor Agama adalah sebagai berikut:

Tabel. 3.12. Hasil Penghitungan Seemingly Unrelated Regression untuk Sektor Agama

\begin{tabular}{|l|c|}
\hline Keterangan & $\begin{array}{c}\text { Ln PDRB Per } \\
\text { Kapita }\end{array}$ \\
\hline Krisis Ekonomi & $-0.0934^{*}$ \\
& $(0.0519)$ \\
\hline Penerimaan Pemerintah Rutin & $-14.7627^{* * *}$ \\
& $(5.0132)$ \\
\hline Penerimaan Pajak (Tax Revenue) & $0.4849^{\star * *}$ \\
& $(0.1140)$ \\
\hline Investasi Daerah & $0.8936^{* * *}$ \\
& $(0.1415)$ \\
\hline Initial PDRB & $-0.0012^{*}$ \\
\hline
\end{tabular}


Bayu Kharisma, dan Adji Pratikto. Pengeluaran Pemerintah dan Pertumbuhan ......

\begin{tabular}{|l|c|}
\hline & $(0.0057)$ \\
\hline Tingkat Harapan Hidup & $4.0398^{* * *}$ \\
& $(0.3330)$ \\
\hline Pengeluaran Pembangunan Pemerintah Sektor Agama & -0.2192 \\
& $(0.197)$ \\
\hline _cons & $12.2329^{* * *}$ \\
& $(1.3800)$ \\
\hline R-sq & 0.3573 \\
\hline chi2 & 299.93 \\
\hline Obs & 546 \\
\hline
\end{tabular}

Sumber : Hasil Perhitungan

Dalam Tabel 3.12 di atas, terlihat bahwa sektor agama juga tidak berpengaruh secara signifikan terhadap pertumbuhan ekonomi. Akan tetapi berbeda dengan empat sektor sebelumnya, pengaruh dari pengeluaran pembangunan sektor agama terhadap pertumbuhan ekonomi bersifat negatif, walaupun tidak signifikan.

\subsection{Sektor Ilmu Pengetahuan dan Teknologi}

Adapun hasil penghitungan untuk pengeluaran pembangunan sektor Ilmu pengetahuan dan teknologi adalah sebagai berikut:

Tabel. 3.13. Hasil Penghitungan Seemingly Unrelated Regression untuk Sektor Ilmu Pengetahuan dan Teknologi

\begin{tabular}{|c|c|}
\hline Keterangan & $\begin{array}{l}\text { Ln PDRB Per } \\
\text { Kapita }\end{array}$ \\
\hline Krisis Ekonomi & $\begin{array}{l}-0.0969^{*} \\
(0.0518)\end{array}$ \\
\hline Penerimaan Pemerintah Rutin & $\begin{array}{c}-17.5239 * * * \\
(5.7263)\end{array}$ \\
\hline Penerimaan Pajak (Tax Revenue) & $\begin{array}{c}0.4928^{* * *} \\
(0.1145)\end{array}$ \\
\hline Investasi Daerah & $\begin{array}{l}0.8884^{\star * *} \\
(0.1413)\end{array}$ \\
\hline Initial PDRB & $\begin{array}{l}-0.0012^{* *} \\
(0.0057)\end{array}$ \\
\hline Tingkat Harapan Hidup & $\begin{array}{l}4.0624^{\star * *} \\
(0.3330)\end{array}$ \\
\hline Pengeluaran Pembangunan Pemerintah Sektor Ilmu pengetahuan dan teknologi & $\begin{array}{c}0.1779 \\
(0.2473) \\
\end{array}$ \\
\hline _cons & $\begin{array}{c}12.14077^{* * *} \\
(1.3799)\end{array}$ \\
\hline R-sq & 0.3579 \\
\hline chi2 & 300.47 \\
\hline Obs & 546 \\
\hline
\end{tabular}

Sumber : Hasil Perhitungan

Pada Tabel 3.13. di atas, terlihat bahwa pengeluaran pembangunan sektor ilmu pengetahuan dan teknologi tidak berpengaruh secara signifikan terhadap pertumbuhan ekonomi. Akan tetapi yang cukup menarik ialah bahwa pengaruhnya 
adalah positif walaupun tidak signifikan, yang sejalan dengan kesimpulan bahwa pengeluaran untuk pembangunan sumberdaya manusia berpengaruh positif walaupun tidak signifikan.

\subsection{Sektor Hukum}

Adapun hasil penghitungan untuk pengeluaran pembangunan sektor hukum adalah sebagai berikut:

Tabel. 3.14. Hasil Penghitungan Seemingly Unrelated Regression untuk Sektor Hukum

\begin{tabular}{|c|c|}
\hline Keterangan & $\begin{array}{l}\text { Ln PDRB Per } \\
\text { Kapita }\end{array}$ \\
\hline Krisis Ekonomi & $\begin{array}{c}-0.0895^{*} \\
(0.0517)\end{array}$ \\
\hline Penerimaan Pemerintah Rutin & $\begin{array}{c}-13.3094^{* * *} \\
(4.7364)\end{array}$ \\
\hline Penerimaan Pajak (Tax Revenue) & $\begin{array}{c}0.5006^{* * *} \\
(0.1145)\end{array}$ \\
\hline Investasi Daerah & $\begin{array}{l}0.8885^{* * *} \\
(0.4110)\end{array}$ \\
\hline Initial PDRB & $\begin{array}{c}-0.0013^{* *} \\
(0.0015)\end{array}$ \\
\hline Tingkat Harapan Hidup & $\begin{array}{l}4.0388^{* * *} \\
(0.3316)\end{array}$ \\
\hline Pengeluaran Pembangunan Pemerintah Sektor Hukum & $\begin{array}{l}-0.8550 \\
(0.7117) \\
\end{array}$ \\
\hline _cons & $\begin{array}{c}12.2351^{* * *} \\
(1.3743)\end{array}$ \\
\hline R-sq & 0.3590 \\
\hline chi2 & 300.47 \\
\hline Obs & 546 \\
\hline
\end{tabular}

Sumber : Hasil Perhitungan

Pada Tabel 3.14 di atas terlihat bahwa pengeluaran pembangunan sektor hukum tidak berpengaruh secara signifikan terhadap pertumbuhan ekonomi.

\subsection{Sektor Aparatur Pemerintah Dan Pengawasan}

Dari hasil penghitungan yang telah dilakukan, didapatkan tabel di bawah ini:

Tabel. 3.15. Hasil Penghitungan Seemingly Unrelated Regression untuk Sektor Aparatur Pemerintah dan Pengawasan

\begin{tabular}{|c|c|}
\hline Keterangan & $\begin{array}{l}\text { Ln PDRB Per } \\
\text { Kapita }\end{array}$ \\
\hline Krisis Ekonomi & $\begin{array}{l}-0.0850 \\
(0.0524)\end{array}$ \\
\hline Penerimaan Pemerintah Rutin & $\begin{array}{c}-9.779 \\
(6.9055)\end{array}$ \\
\hline Penerimaan Pajak (Tax Revenue) & $0.4726^{* * *}$ \\
\hline
\end{tabular}




\begin{tabular}{|c|c|}
\hline & $(0.1144)$ \\
\hline Investasi Daerah & $\begin{array}{c}0.9069^{* * *} \\
(0.1418)\end{array}$ \\
\hline Initial PDRB & $\begin{array}{c}-0.0012^{* *} \\
(0.0057)\end{array}$ \\
\hline Tingkat Harapan Hidup & $\begin{array}{l}3.9642^{* *} \\
(0.3409)\end{array}$ \\
\hline $\begin{array}{lllllll}\text { Pengeluaran Pembangunan } & \text { Pemerintah Sektor Aparatur Pemerintah dan } \\
\text { Pengawasan } & & & & \\
\end{array}$ & $\begin{array}{l}-0.5312 \\
(0.2473)\end{array}$ \\
\hline _cons & $\begin{array}{c}12.547^{* * *} \\
(1.4127)\end{array}$ \\
\hline R-sq & 0.3584 \\
\hline chi2 & 301.22 \\
\hline Obs & 546 \\
\hline
\end{tabular}

Sumber : Hasil Perhitungan

Sama seperti sektor sebelumnya, pengeluaran pemerintah untuk sektor aparatur pemerintah dan pengawasan juga tidak berpengaruh signifikan terhadap pertumbuhan ekonomi.

\subsection{Sektor Politik, Penerangan, Komunikasi dan Media Massa}

Adapun hasil penghitungan untuk pengeluaran pembangunan sektor politik, penerangan, komunikasi dan media massa adalah sebagai berikut:

Tabel. 3.16. Hasil Penghitungan Seemingly Unrelated Regression untuk Sektor Politik, Penerangan, Komunikasi dan Media Massa

\begin{tabular}{|c|c|}
\hline Keterangan & $\begin{array}{l}\text { Ln PDRB Per } \\
\text { Kapita }\end{array}$ \\
\hline Krisis Ekonomi & $\begin{array}{l}-0.0802 \\
(0.0518)\end{array}$ \\
\hline Penerimaan Pemerintah Rutin & $\begin{array}{l}-11.1692^{* *} \\
(4.8460)\end{array}$ \\
\hline Penerimaan Pajak (Tax Revenue) & $\begin{array}{l}0.4797^{* *} \\
(0.1144)\end{array}$ \\
\hline Investasi Daerah & $\begin{array}{c}0.9042^{* * *} \\
(0.1407)\end{array}$ \\
\hline Initial PDRB & $\begin{array}{c}-0.0012^{* * *} \\
(0.0057)\end{array}$ \\
\hline Tingkat Harapan Hidup & $\begin{array}{c}3.9584^{* * *} \\
(0.3329)\end{array}$ \\
\hline $\begin{array}{l}\text { Pengeluaran Pembangunan Pemerintah Sektor Politik, Penerangan, Komunikasi } \\
\text { dan Media Massa }\end{array}$ & $\begin{array}{l}-0.5081 \\
(0.2355)\end{array}$ \\
\hline _cons & $\begin{array}{c}12.5698^{* * *} \\
(1.3797)\end{array}$ \\
\hline R-sq & 0.3627 \\
\hline chi2 & 306.88 \\
\hline
\end{tabular}

Sumber : Hasil Perhitungan 
Dari tabel di atas, terlihat bahwa pengeluaran pembangunan sektor politik berpengaruh negatif dengan taraf signifikansi $5 \%$.

\subsection{Sektor Keamanan Dan Ketertiban Umum}

Adapun hasil penghitungan untuk pengeluaran pembangunan sektor keamanan dan ketertiban umum adalah sebagai berikut:

Tabel. 3.17. Hasil Penghitungan Seemingly Unrelated Regression untuk Sektor Keamanan dan Ketertiban Umum

\begin{tabular}{|l|c|}
\hline \multicolumn{1}{|c|}{ Keterangan } & $\begin{array}{c}\text { Ln PDRB Per } \\
\text { Kapita }\end{array}$ \\
\hline Krisis Ekonomi & $-0.1023^{*}$ \\
& $(0.0515)$ \\
\hline Penerimaan Pemerintah Rutin & $-17.8638^{* * *}$ \\
& $(4.6591)$ \\
\hline Penerimaan Pajak (Tax Revenue) & $0.5043^{* * *}$ \\
& $(0.1135)$ \\
\hline Investasi Daerah & $0.8992^{* * *}$ \\
& $(0.1405)$ \\
\hline Initial PDRB & $-0.0013^{* * *}$ \\
& $(0.0057)$ \\
\hline Tingkat Harapan Hidup & $4.0270^{* * *}$ \\
& $(0.3303)$ \\
\hline Pengeluaran Pembangunan Pemerintah Sektor Keamanan dan Ketertiban Umum & -0.6389 \\
\hline cons & $(0.2658)$ \\
\hline R-sq & $12.2976^{* * *}$ \\
\hline chi2 & $(1.3692)$ \\
\hline Obs & 0.3640 \\
\hline
\end{tabular}

Sumber : Hasil Perhitungan

Pada Tabel 3.17 diatas, terlihat bahwa pengeluaran pembangunan sektor keamanan dan ketertiban umum berpengaruh positif dengan taraf signifikansi 5\%. Hal ini sangat menarik, karena menjadi satu-satunya sektor yang berpengaruh positif dan signifikan. 


\section{Kesimpulan}

Pada 17 sektor yang diteliti, hanya 6 sektor yang berpengaruh secara signifikan terhadap pertumbuhan ekonomi, yaitu sektor industri, sektor pertanian dan pengairan, sektor transportasi dan perhubungan, sektor lingkungan hidup dan tata ruang, sektor politik dan penerangan media massa, dan keamanan ketertiban. Dari ke enam sektor tersebut, hanya sektor keamanan ketertiban yang berpengaruh secara positif terhadap pertumbuhan ekonomi, sedangkan ke 5 sektor lainnya berpengaruh secara negatif terhadap pertumbuhan ekonomi.

Apabila tidak diperhatikan taraf signifikansinya, hampir keseluruhan sektor pengeluaran pembangunan memiliki pengaruh yang negatif terhadap pertumbuhan ekonomi, hanya 5 sektor yang memiliki pengaruh positif yaitu sektor tenaga kerja, sektor pendidikan, kebudayaan nasional, kepercayaan terhadap Tuhan YME, pemuda dan olahraga, sektor perumahan dan pemukiman, sektor ilmu pengetahuan dan teknologi, serta sektor keamanan dan ketertiban. Akan tetapi hanya sektor keamanan ketertiban yang berpengaruh secara signifikan, sedangkan ke empat sektor lainnya tidak berpengaruh secara signifikan. Hasil temuan ini berbeda dengan kesimpulan yang didapat dari Niloy Bose et al (2007), di mana kesimpulan keseluruhan sektor pengeluaran pembangunan pemerintah yang berpengaruh signifikan, pengaruhnya adalah positif. Akan tetapi kesimpulan yang sama dihasilkan untuk sektor keamanan dan ketertiban, di mana hasilnya adalah positif dan signifikan. Dengan demikian, dapat disimpulkan bahwa hampir keseluruhan pembangunan pemerintah tidak berpengaruh secara signifikan terhadap pertumbuhan ekonomi.

Apabila dibahas mengenai variabel lainnya, terdapat kesimpulan yang menarik bahwa setelah kita mengontrol ke 17 sektor pengeluaran pembangunan tersebut, variabel pendapatan pajak (tax revenue) selalu berpengaruh secara positif dan signifikan terhadap pertumbuhan ekonomi. Dengan demikian, dapat disimpulkan bahwa masih terdapat ruang yang cukup besar bagi pemerintah daerah 
untuk lebih mendorong peningkatan pendapatan pajak tanpa melakukan distorsi pasar.

Hal lainnya yang cukup menarik adalah bahwa pengeluaran rutin pemerintah, selalu berpengaruh negatif terhadap pertumbuhan ekonomi, walaupun terdapat beberapa hasil yang menunjukkan signifikan dan tidak signifikan, setelah kita mengontrol salah satu dari ke 17 sektor pengeluaran pembangunan pemerintah. Hal ini kemungkinan berarti bahwa pemerintah daerah sebaiknya melakukan penghematan untuk pengeluaran rutin-nya agar dapat mendorong pertumbuhan ekonomi. Dengan demikian, dapat disimpulkan bahwa kinerja dari pemerintahan daerah belum efisien, karena mungkin jumlah pegawai pemerintah daerah masih terlalu besar daripada yang dibutuhkan.

Sebenarnya kesimpulan ini masih perlu dilihat lebih jauh lagi untuk melihat darimana sumber inefisiensi pemerintah tersebut, apakah berasal dari belanja pegawai atau yang lainnya, karena di dalam penelitian ini, kami hanya menggunakan total pengeluaran rutin saja, tanpa memilah satu persatu bagian di dalam pengeluaran rutin tersebut. Selain itu, apabila kita melihat pengaruh dari investasi swasta terhadap pertumbuhan ekonomi, kesimpulan yang sama dihasilkan dengan penelitian dari Niloy Bose et al (2007), karena di dalam penelitian ini juga dihasilkan kesimpulan bahwa pengaruhnya adalah positif dan signifikan, setelah dikontrol ke 17 sektor pengeluaran pembangunan. Dengan demikian, penelitian ini juga mendukung kesimpulan dari model neoklasik, yang menyimpulkan bahwa investasi berpengaruh positif terhadap pertumbuhan ekonomi.

\section{DAFTAR PUSTAKA}

Barro, R. J. and J. W. Lee (1994). "Sources of Economic Growth." Carnegie-Rochester Conference Series on Public Policy 40: pp. 1 - 46.

Bose, N., M. E. Haque, et al. (2007). "Public Expenditure and Economic Growth: A Disaggregated Analysis for Developing Countries." Manchester School 75(5): pp. $533-556$. 
Bayu Kharisma, dan Adji Pratikto. Pengeluaran Pemerintah dan Pertumbuhan ......

Mankiw, N. G. (2009). Principles of Economics, South Western Cengage Learning.

Zellner, A. (1962). "An Efficient Method of Estimating Seemingly Unrelated Regressions and Tests for Aggregation Bias." Journal of the American Statistical Association 57(No. 298): pp.348-368. 